Article

\title{
Assessing Liveable Cities for Older People in an Urban District in Turkey Using the Analytical Hierarchy Process
}

\author{
Ercüment Aksoy ${ }^{1}$ and Nilufer Korkmaz-Yaylagul ${ }^{2, *}$ \\ ${ }^{1}$ Department of Geographical Information System, Akdeniz University, 07070 Antalya, Turkey; \\ E-Mail: ercumentaksoy@akdeniz.edu.tr \\ 2 Department of Gerontology, Akdeniz University, 07070 Antalya, Turkey; E-Mail: niluferyaylagul@akdeniz.edu.tr \\ * Corresponding author
}

Submitted: 21 December 2018 | Accepted: 5 March 2019 | Published: 18 June 2019

\begin{abstract}
The key concepts availability and accessibility have been taken into consideration in urban studies as well as the health and social aspects of ageing. These terms are in close relation with the "active ageing", "age-friendly city" and "liveable city" concepts. These concepts were created by the UN, the World Health Organization, and other institutions aiming to increase the quality of life of older individuals and to regulate their living environments in an optimal way for an active and independent life. Improving accessibility and availability of facilities for older people in urban areas is crucial to ensure that older people are able to meet their own needs as well as prevent their exclusion from society. The planning of cities that prevents the social exclusion of older people and provides an independent way of living is the main objective of the concept of liveable cities. From this point of view, this study aims to evaluate the existing opportunities in an urban area in the context of liveability. Out of the multi-criteria decision-making models, analytic hierarchy process (AHP) and geographic information systems (GIS) were therefore used in this research. Three main districts of Kepez, with the highest population of older individuals, have been chosen. According to the findings of the study, the weight of health services has the highest score compared to other criteria. The liveability scores and grading of the districts were obtained using the AHP matrix. In the study, it was concluded that a multi-criteria analysis could be carried out with quantitative data. The real land use and the close environment of the research area should also be considered in the evaluation process.
\end{abstract}

\section{Keywords}

accessibility; analytic hierarchy process; liveable city; old age; social exclusion

\section{Issue}

This article is part of the issue "The City, Aging and Urban Planning", edited by Matthias Drilling (University of Applied Sciences and Arts Northwestern Switzerland) and Fabian Neuhaus (University of Calgary, Canada).

(C) 2019 by the authors; licensee Cogitatio (Lisbon, Portugal). This article is licensed under a Creative Commons Attribution 4.0 International License (CC BY).

\section{Introduction}

Cities are places with not only physical, but also social and cultural dimensions in terms of living areas and production. Contemporarily, two worldwide developments in the population affect urban planning. First, more than half of the world's population lives in cities and this rate is increasing. Today, $55 \%$ of the world's population lives in urban areas and this rate is expected to increase to $68 \%$ by 2050 (UN, 2018). Secondly, the proportion of older people aged 65 and over living in urban areas is increasing parallel to the increase in the older population. In 2015, 58\% of individuals over 65 years of age were living in urban areas, and the population of people aged 65 and over living in urban areas across the world increased by $68 \%$ between 2000 and 2015 . However, this rate has only increased by $25 \%$ in rural areas over 15 years (UN, 2015).

According to the UN-Habitat (2010) report, older people living in cities are among the most excluded groups 
and are at greater risk regarding social isolation. Social isolation has been studied in two dimensions: objective measured social isolation, and emotional isolation. Gardner, Brooke, Ozanne and Kendig (1999) defined people with negative outcomes of poor or limited social contact as socially isolated (cited in Findlay, 2003). Studies indicate that older individuals experience disadvantages with regards to accessing services in urban areas (Findlay, 2003; Ogg, 2005). Disadvantages affecting older individuals are found mainly in accessing health care services and in their social interaction (Luo \& Wang, 2003; Mollenkopf et al., 2004; Wahl, Iwarsson, \& Oswald, 2012). The concept of accessibility is defined by Nicholls (2001) as the convenience with which a place or service can be reached or obtained. Therefore, it can be said that accessibility in urban areas is the access to physical and social resources that are effective in providing quality of life and well-being to individuals living in cities. Equal access to basic health care, long-term health care, and social services is essential for active ageing (Beard \& Petitot, 2010; Kalache, 2016; Luo \& Wang, 2003; Warner, Xu, \& Morken, 2017).

Active Aging: A Policy Framework Report by the World Health Organization (WHO) has defined active ageing as not only staying physically active but also ensuring to continue the participation of older individuals in social, cultural, economic, and civic areas (WHO, 2002). The main objective of the active ageing concept is to ensure that the individual is ageing independently and autonomously. Active ageing is based on three criteria set by the WHO (2002): health, participation, and security. In this context, active ageing is defined as the optimisation of health, participation, and security opportunities to improve the quality of life of individuals. This global trend has affected the direction of approaches to urban planning. Efforts towards a supportive urban planning model should take the ageing population into consideration. The implementation should start with the planning of living environments. Living environments provide support in order to meet the daily activities at the optimum level. It also indirectly shapes psycho-social factors that affect the quality of life and well-being (Paul \& Sen, 2018; Ruth \& Franklin, 2014). The goal is to apply the global trends of population ageing and urbanisation into a model of urban planning to ensure older people remain active and engaged in society with appropriate spatial facilities (Bookman, 2008).

The WHO developed a programme in 2006 named "Age-Friendly Cities and Communities" to arrange the living environment of older people and encourage active ageing (WHO, 2007). Transportation, housing, social participation, respect and social inclusion, civic participation and employment, communication and information, community and health services, and outdoor spaces and buildings have been constituted as the main domains for age-friendly cities. Features of a city's physical environment may have an influence on personal mobility, safety, security, health behaviour, and social par- ticipation (Beard \& Montawi, 2015; Buffel, Phillipson, \& Scharf, 2012; Moulaert \& Garon, 2015; Steels, 2015). The WHO Global Network of Age-Friendly Cities has defined four stages to use as guidance for the evaluation of agefriendly cities: planning, implementation, progress evaluation, and continual improvement. The evaluation of age-friendly cities is a complex and time-consuming process. The planning and implementation stages require a 3-year city-wide plan of action based on assessment findings. Varied models of age-friendly cities are identified in the literature. While some models focus on physical environment and design (Atlanta Regional Commission, 2009), others (e.g., the UK model of Lifetime Neighbourhoods) mainly focus on social aspects of the environment (from the Department for Communities and Local Government, cited in Shank \& Cutchin, 2016). One of the age-friendly cities' initiatives - the liveable cities concept, which is not independent of the age-friendly city concepts principles-has been widely used in the literature (Biggs \& Carr, 2015; Fidler, Olson, \& Bezold, 2011; Shank \& Cutchin, 2016; Steels, 2015). The concept of liveable cities is concerned with land use, urban and suburban features, and efficient use of existing infrastructure. Liveability is conceptualised as the determination or development of the presence, absence, or relative weight of some variables in a physical or social context. According to the AARP (2005, cited in Hwang \& Ziebarth, 2015; formerly American Association of Retired Persons), a liveable community is defined as an age-friendly community fostering healthy living and active ageing. Planning a liveable community consists of transportation efficiency, local assets, affordable housing, and walkable neighbourhoods (cited in Hwang \& Ziebarth, 2015). There are many pieces of research in the literature regarding whether the existing infrastructure and services meet the needs of individuals and whether individuals can access these opportunities (Jensen \& Maslesa, 2015; Luo \& Wang, 2003; Nicholls, 2001; Warner et al., 2017). However, very little attention is paid to whether these characteristics exist in the living environment of older individuals or whether they are adequate (Shank \& Cutchin, 2016; Wey \& Huang, 2018).

Priorities of existing infrastructure and services may vary according to the living environment and might change according to individual needs (Ruth \& Franklin, 2014; Shank \& Cutchin, 2016). In his literature review, Steels (2015) found varieties in the implementation of the concepts of age-friendly cities and has asserted that the local socio-economic and cultural features need to be considered when determining types of age-friendly initiatives. Priorities might change according to socioeconomic and cultural features. Groups with a low education profile were found to attend leisure activities less and religious practices more frequently than groups with a higher education profile (Steels, 2015). Thus, the purpose of this article is to evaluate the priorities of spatial facilities and their weight in order to create a liveable agefriendly environment from the local perspective. 


\section{Research Field}

Antalya city is located in the south of Turkey and is not in the age-friendly cities network. Kepez, the central district with the largest population has been selected for the research field. According to the Turkish Statistical Institute's (TURKSTAT) population data of 2017, Kepez has a population of 519,966 . The $65+$ population is 41,640 , being the highest in number of older individuals among the districts of Antalya city. The population of Kepez is socially and economically disadvantaged compared to other districts and there is no spatially administrative study about the development of urban facilities for older people in this region. Therefore, it has been selected as the research area. As a still developing region, it is hoped that Kepez will benefit from the research results from the aspect of urban planning. The location map of Kepez is shown in Figure 1.

\section{Method}

Creating a liveable environment for older individuals is a complex and multi-criteria decision-making process. Therefore, there is a need for an analysis tool where different criteria can be evaluated. The analysing process is difficult in scientific and applied research because of the diversification and the high number of criteria types. Out of multi-criteria decision-making methods, analytic hierarchy process (AHP) such as Topsis, Prometee, Electre, etc., have been increasingly used in several disciplines such as economics, health, education, and spatial planning.

AHP, based on mathematical theory, and one of the commonly used multi-criteria decision analysis (MCDA) methods, was developed by Saaty in 1980 and enables a comparison between indicators (Saaty, 1980). It is suitable for systematic and hierarchical evaluation that combines qualitative and quantitative methods. It examines, simplifies, and solves complex problems according to their interactions (Yu, Liu, Chang, Ma, \& Yang, 2011; Zarghami, Sharghi, Olfat, \& Kousalari, 2018). With this method, each decision maker has the authority to determine the weight of the criteria and the criteria according to his expertise, point of view, and degree of emphasis.

\section{Criteria Selection and AHP Process}

This research attempts to evaluate the grading and the availability of facilities offered to older people comparing multiple aspects. In this study, AHP analysis is used, and the neighbourhood-based evaluation of the criteria, which was determined in the research, was conducted using geographic information systems (GIS; see Figure 2).

A two-staged criteria selection has been carried out. In the first stage, a detailed literature search about agefriendly cities initiatives, their targets, criteria, and applications, was carried out. An expert group of 15 older individuals at the age of 65 and over living in Kepez region and five academicians with a background in urban planning and ageing has been created in the second stage. Accordingly, the expert group has been informed about the study and the research question was asked: what are the main facilities for an autonomous, independent, healthy, and active life for older people in a local neighbourhood?

The results and their frequencies have been recorded using the fishbone method (Yazdani \& TavakkoliMoghaddam, 2012). Ten criteria were obtained according to the frequencies: oral and dental health centres,

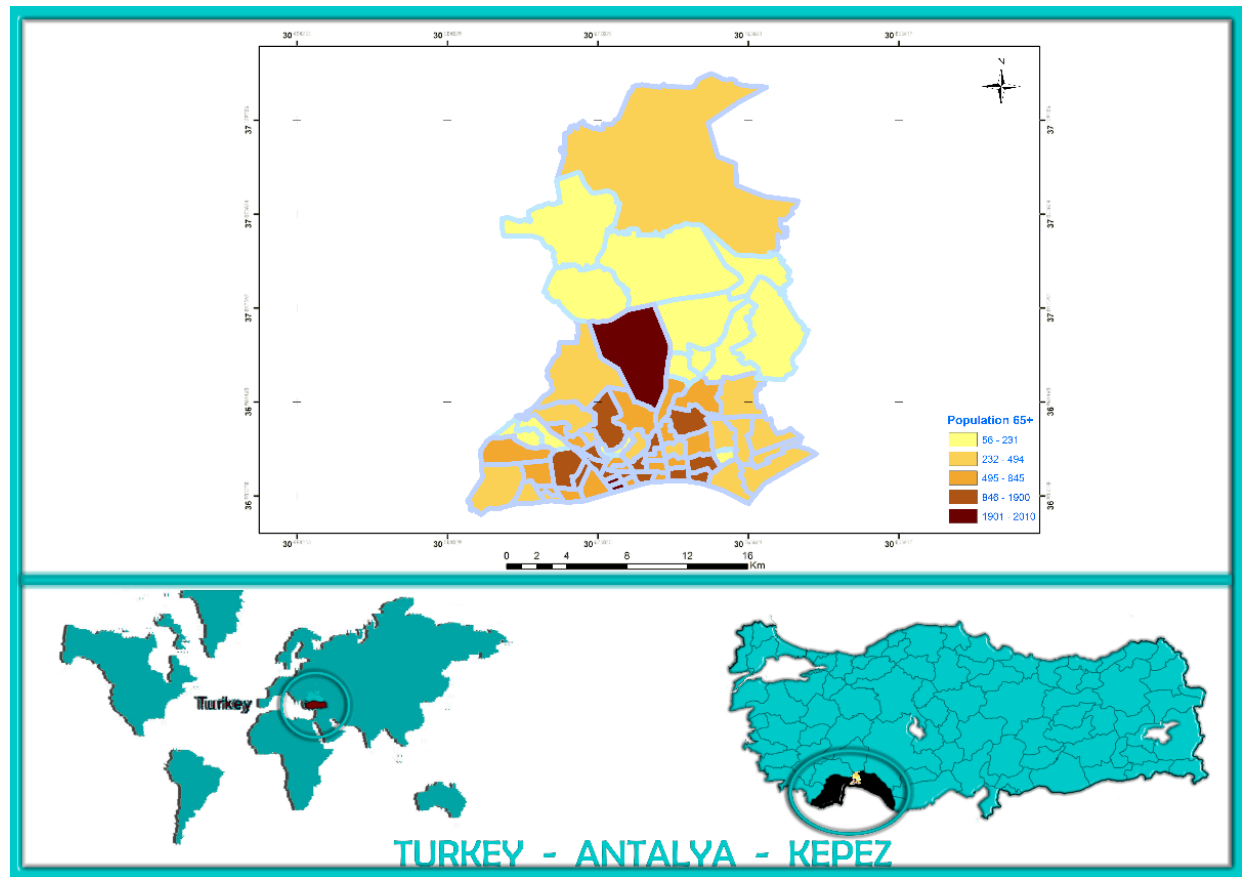

Figure 1. Kepez district and neighbourhood locations. 


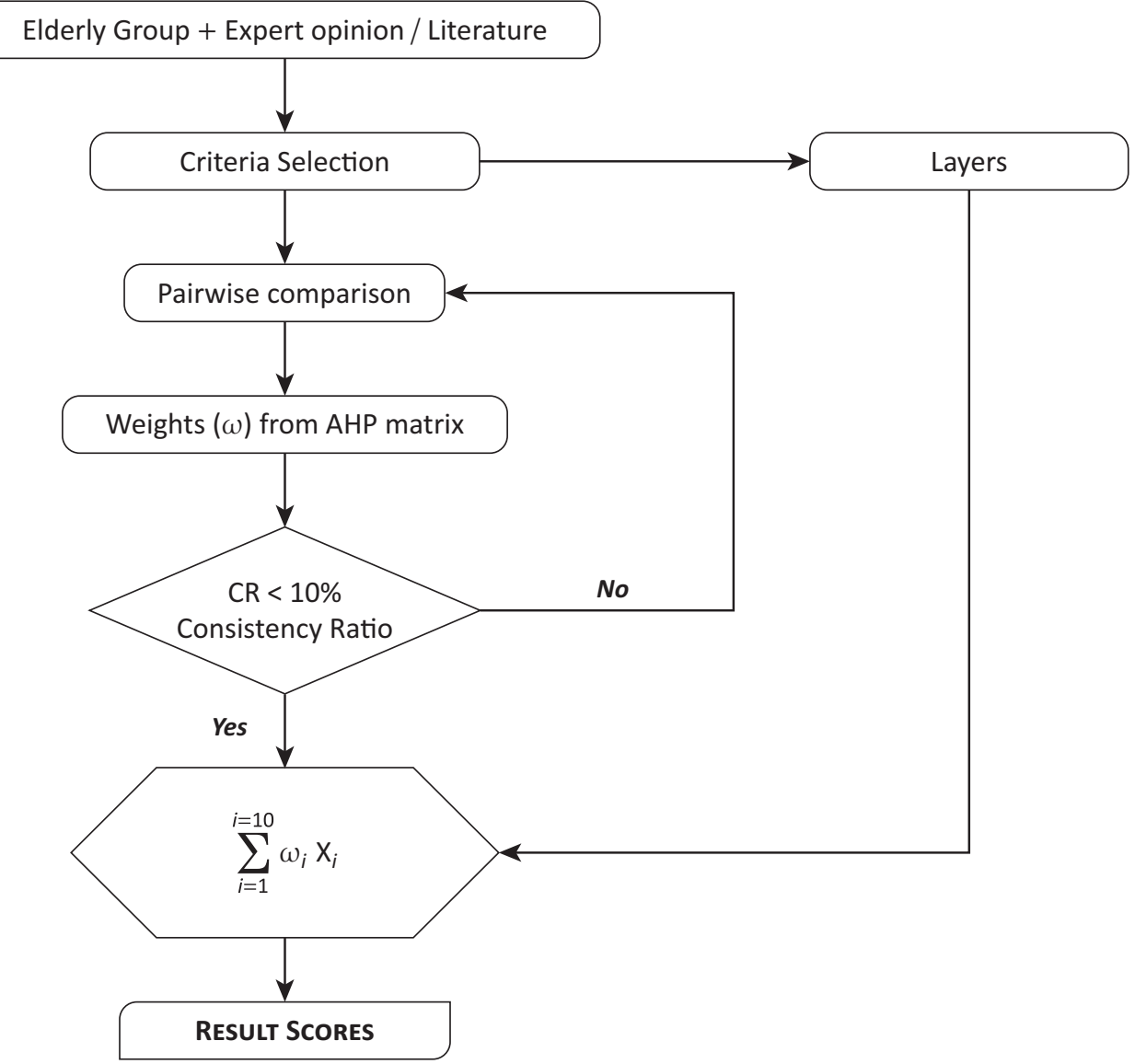

Figure 2. Flow chart of the proposed AHP approach. Notes: $X_{i}=$ Layer Counts $=$ Oral and dental health centres, ambulance centres, primary health care centres, pharmacies and transportation network, ATMs, parks, and stops; $\omega_{i}=$ Total Score of Criteria.

ambulance, pharmacies, hospitals, primary health care centres related to health care services and roads, bus and tram stops, automatic teller machines (ATMs), mosques, and parks. These criteria have been compared with the concept of age-friendly cities and were found to be coherent regarding the main domains of age-friendly cities (transportation, housing, social participation, respect and social inclusion, civic participation and employment, communication and information, community and health services, and outdoor spaces and buildings). Accordingly, all proposed criteria have been included in the analysis.

The respondents were asked to weight the criteria between 1 and 9 according to the importance. The same degree score may be given to more than one criterion and there is no need for all scores to be in the rating charts (Table 1).

The mean weight of criteria has been calculated and the criteria were scored as below: ambulance 9, primary health care centres 8 , bus and tram stops 7 , pharmacies and hospitals 6 , mosques 5 , parks and dental health 4, ATMs 3, and roads 1 . The highest score was given to ambulance service because of the vital importance of emergency health assistance in terms of advanced age. Primary health care services have been rated with 8 points considering that they are the most fre- quently used health centres for older people. Bus stops have been rated with 7 points in terms of mobility of the individuals living in the region. Pharmacies and hospitals giving long-term health care service have been rated with 6 points. Mosques are religious places that can be visited regularly. Mosques have been rated with 5 points. Parks have been rated with 4 points as places where older individuals can spend their leisure time. The transportation network has been rated with a score of 3 and the ATMs with a score of 1 . The final criteria were calculated by placing these rating scores in the AHP analysis of the criteria matrix (Table 2 ) in order to find a general weight between the criteria with a paired comparison.

Table 1. Gradation scale for quantitative comparison of criteria.

\begin{tabular}{lc}
\hline Option & Numerical value(s) \\
\hline Equal & $\mathbf{1}$ \\
Marginally strong & $\mathbf{3}$ \\
Strong & $\mathbf{5}$ \\
Very strong & $\mathbf{7}$ \\
Extremely strong & $\mathbf{9}$ \\
Intermediate values & $\mathbf{2 , 4 , 6 , 8}$ \\
\hline
\end{tabular}


Table 2. AHP analysis of the criteria.

\begin{tabular}{|c|c|c|c|c|c|c|c|c|c|c|c|c|}
\hline & & road & ATM & park & $\begin{array}{l}\text { dental } \\
\text { health }\end{array}$ & mosque & pharmacy & hospital & bus_tram & $\begin{array}{l}\text { primary } \\
\text { health } \\
\text { care }\end{array}$ & ambulance & \\
\hline & & $A$ & $B$ & $C$ & $\mathrm{D}$ & $E$ & $\mathrm{~F}$ & G & $\mathrm{H}$ & 1 & $\mathrm{~J}$ & Weight $(w)$ \\
\hline road & $A$ & 1 & 0,333 & 0,25 & 0,25 & 0,333 & 0,333 & 0,2 & 0,143 & 0,111 & 0,111 & 0,017756 \\
\hline ATM & B & 3 & 1 & 1 & 0,5 & 0,333 & 0,25 & 0,2 & 0,143 & 0,143 & 0,125 & 0,027601 \\
\hline park & $C$ & 4 & 2 & 1 & 0,5 & 0,25 & 0,2 & 0,2 & 0,167 & 0,143 & 0,125 & 0,031832 \\
\hline $\begin{array}{l}\text { dental } \\
\text { health }\end{array}$ & D & 4 & 2 & 1 & 1 & 0,333 & 0,25 & 0,2 & 0,167 & 0,167 & 0,143 & 0,035591 \\
\hline mosque & $E$ & 5 & 3 & 2 & 2 & 1 & 0,333 & 0,333 & 0,2 & 0,2 & 0,167 & 0,055247 \\
\hline pharmacy & $\mathrm{F}$ & 6 & 4 & 3 & 3 & 2 & 1 & 1 & 0,333 & 0,2 & 0,2 & 0,086717 \\
\hline hospital & G & 6 & 4 & 3 & 3 & 2 & 1 & 1 & 1 & 0,5 & 0,333 & 0,103985 \\
\hline $\begin{array}{l}\text { bus_tram } \\
\text { stops }\end{array}$ & $\mathrm{H}$ & 7 & 5 & 4 & 4 & 3 & 2 & 2 & 1 & 1 & 0,5 & 0,152013 \\
\hline $\begin{array}{l}\text { primary } \\
\text { health care }\end{array}$ & 1 & 8 & 6 & 5 & 5 & 4 & 3 & 3 & 2 & 1 & 1 & 0,212156 \\
\hline ambulance & $\mathrm{J}$ & 9 & 7 & 6 & 6 & 5 & 4 & 4 & 3 & 2 & 1 & 0,277102 \\
\hline Total & $\mathrm{T}$ & 53 & 34,33 & 26,25 & 25,25 & 18,25 & 12,37 & 12,13 & 8,152 & 5,463 & 3,704 & 1,000000 \\
\hline
\end{tabular}

Notes: The consistency of the scoring system of these criteria is calculated with the consistency index $(\mathrm{Cl})$ of the paired comparison matrix and the consistency ratio (CR). In the study, $\mathrm{Cl}=0.043$ and $\mathrm{CR}=0.029$ were obtained. The matrix is found to be consistent (the calculated $\mathrm{CR}<0,1$ is accepted for consistency).

Table 3. AHP validity reliability test.

\begin{tabular}{|c|c|c|c|c|c|c|c|c|c|c|c|c|c|c|c|}
\hline $\mathbf{N}$ & 1 & 2 & 3 & 4 & 5 & 6 & 7 & 8 & 9 & 10 & 11 & 12 & 13 & 14 & 15 \\
\hline RI & 0,00 & 0,00 & 0,58 & 0,90 & 1,12 & 1,24 & 1,32 & 1,41 & 1,45 & 1,49 & 1,51 & 1,48 & 1,56 & 1,57 & 1,59 \\
\hline
\end{tabular}

Note: RI stands for random index.

$\mathrm{CR}=\frac{\mathrm{Cl}}{\mathrm{RI}}$

Each criteria layer is placed on both row and column and compared to each other. Accordingly, a scale between 1 and 9 has been given.

A liveability score has been calculated by multiplying the "weight coefficients" generated via AHP matrix, with the number of each criterion of the neighbourhood "liveability score" being considered as a proposed concept in this research. A higher liveability score result indicates a higher fulfilment of expectations from a liveable neighbourhood.

\section{Data Collection}

Quantitative data has been obtained from TURKSTAT, Antalya Municipality and from free web map services in the research. Age groups distribution data was entered to GIS in base maps of Kepez district and age densities maps of neighbourhoods were obtained.

The research field has been divided into neighbourhoods for a more detailed analysis. Three neighbourhoods, Varsak (number of individuals aged 65+ $=2010$ ), Özgürlük (number of individuals aged 65+ = 1999), and
Ulus (number of individuals aged $65+=1941$ ) with the highest population of people aged 65 and older have been obtained from the density map (see Figure 3).

Ten criteria layers including roads, ATMs, parks, oral and dental health centres, mosques, pharmacies, hospitals, bus and tram stops, primary health care centres and ambulance centres have been generated in GIS software to create point types. QGIS, the most widely used open source program in the world, was used as software. The data was transformed into GIS maps as $X, Y$ coordinates, which is called "convert text to maps". This process was followed by the AHP process. A score between 1 and 9, with the paired comparison of layers (criteria), and "weight coefficients of criteria", by means of "weight matrix" of this score, were gathered. The "liveability score" of each neighbourhood was calculated after finding the criterion weights by means of the sum of the multiplications of each neighbourhood's numerical values of criteria with weight coefficient. The ranking of the scores of these three neighbourhoods reveals the "liveability ranking" of the research field. The research model has been given in the flow chart in Figure 4. 


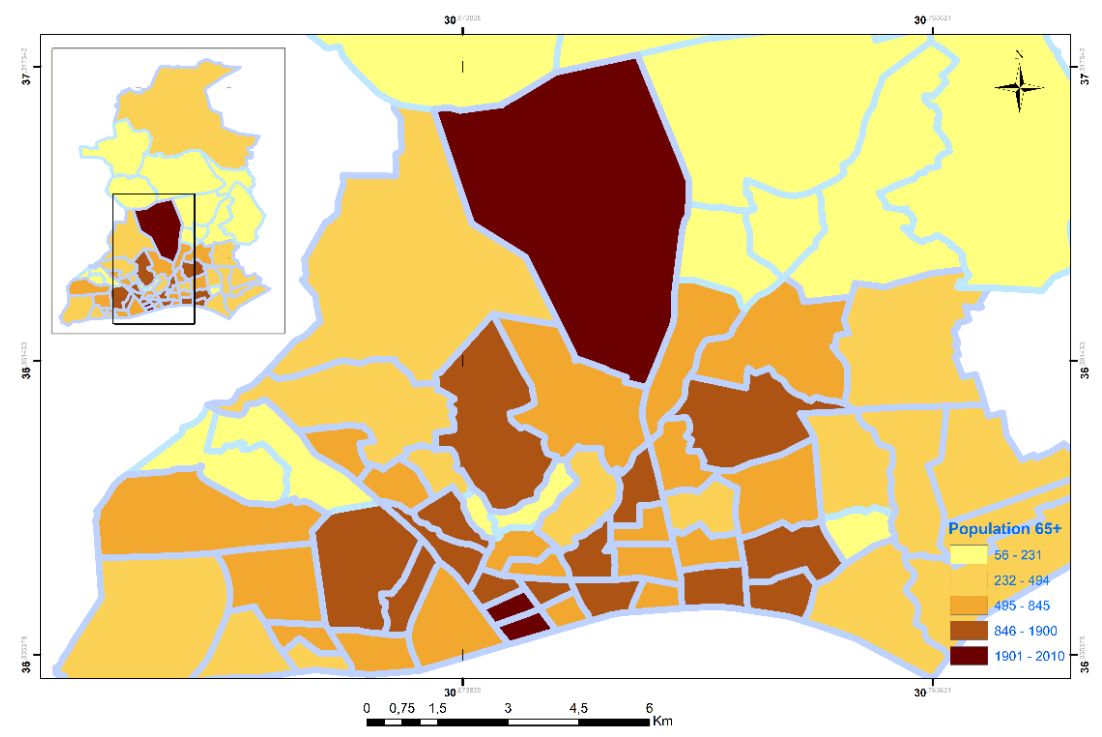

Figure 3. Age density map.

\section{Research Area Selection}

$65+$ the most densely populated district

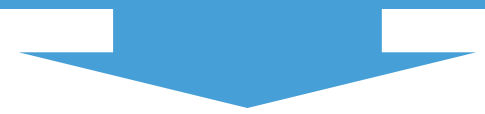

\section{RESEARCH DATA}

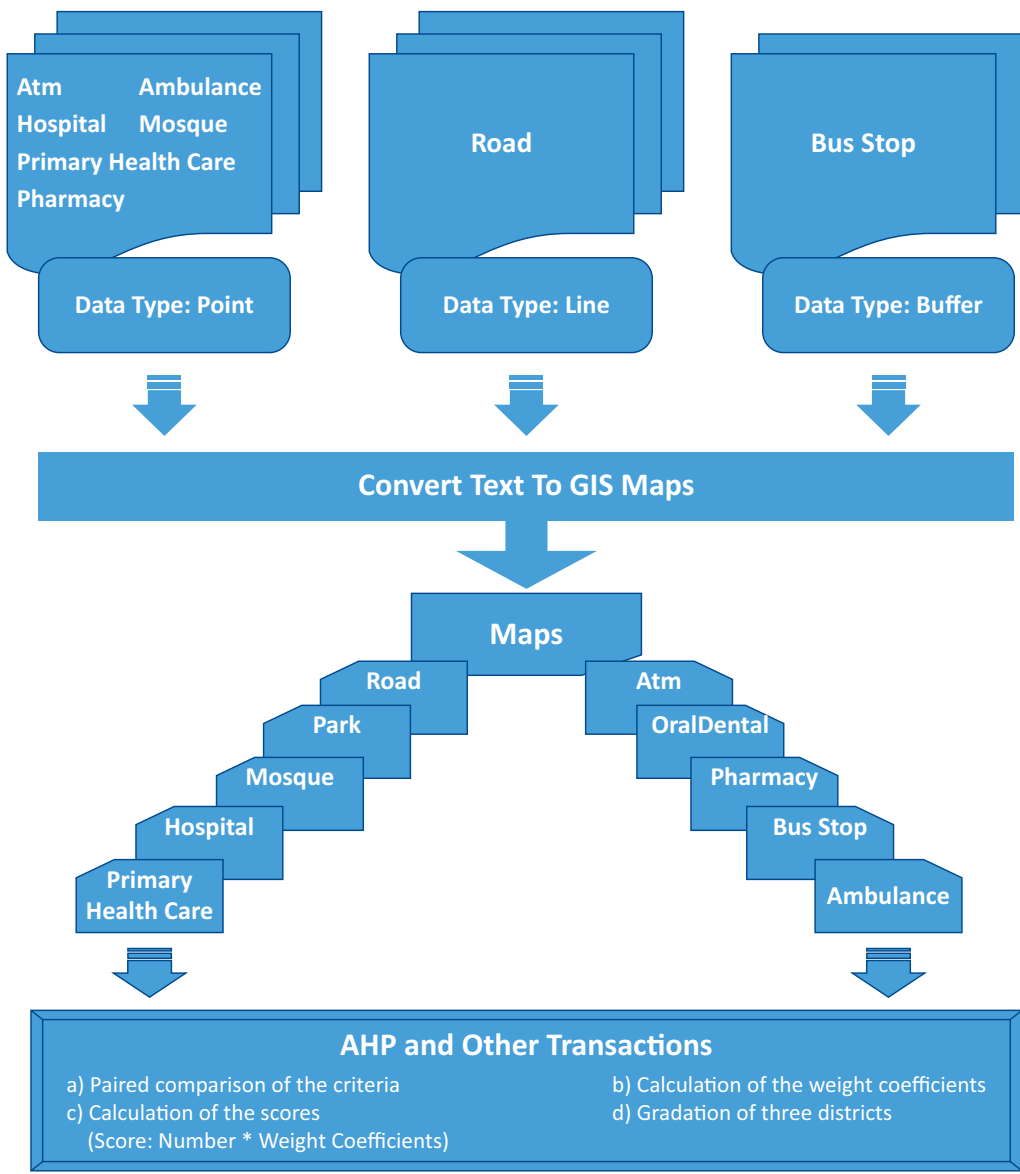

Figure 4. Method flow chart. 


\section{COGITATIO}

\section{Findings}

\subsection{The Point Data of Neighbourhoods}

Coordinate data of the criteria used in the research is converted into point data and placed in these maps using the GIS program. Transportation network data of the neighbourhoods are line-shaped and, in order to transform it into quantitative data, the density of road networks were graded such as: 3 points for high density, 2 points for medium density, and 1 point for low density according to the field size and population density. Maps of the neighbourhoods are seen in Figures 5, 6, and 7.

The findings of the three neighbourhoods were compared with each other according to the criteria. The find- ings of mapping by GIS from the three neighbourhoods are presented below:

- Access to health care services is revealed in Yung, Conejos, and Chan (2016) as one of the most important factors in terms of healthy ageing. There are neither ambulance centres nor hospitals in Ulus, Özgürlük, and Varsak neighbourhoods. This is a vital deficiency for these three neighbourhoods. Ulus neighbourhood has the highest number (nine) of oral and dental health centres and they are spatially relatively homogeneously distributed. However, there are three dental health centres in Özgürlük and one in Varsak. There are primary health care centres in Ulus and Özgürlük

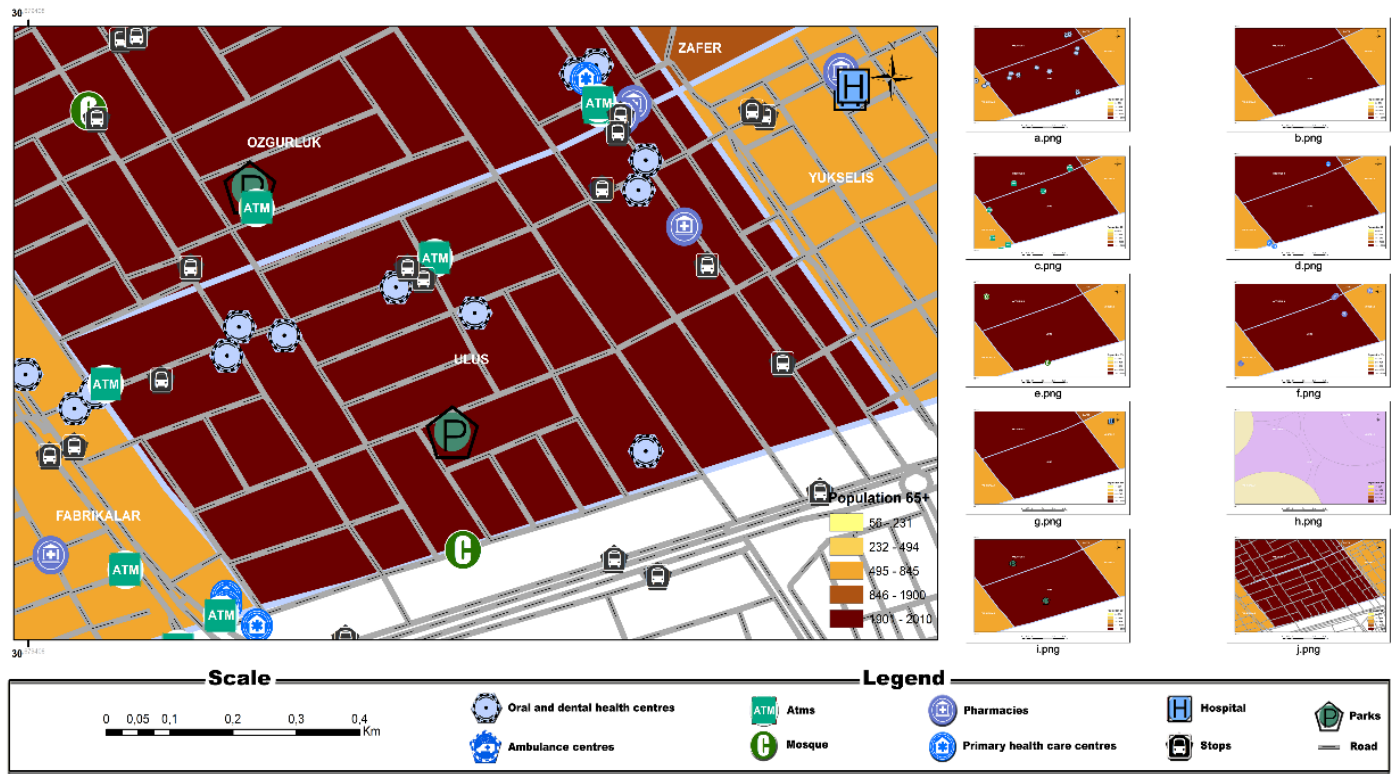

Figure 5. Location and density map of selected criteria in Ulus Neighbourhood.

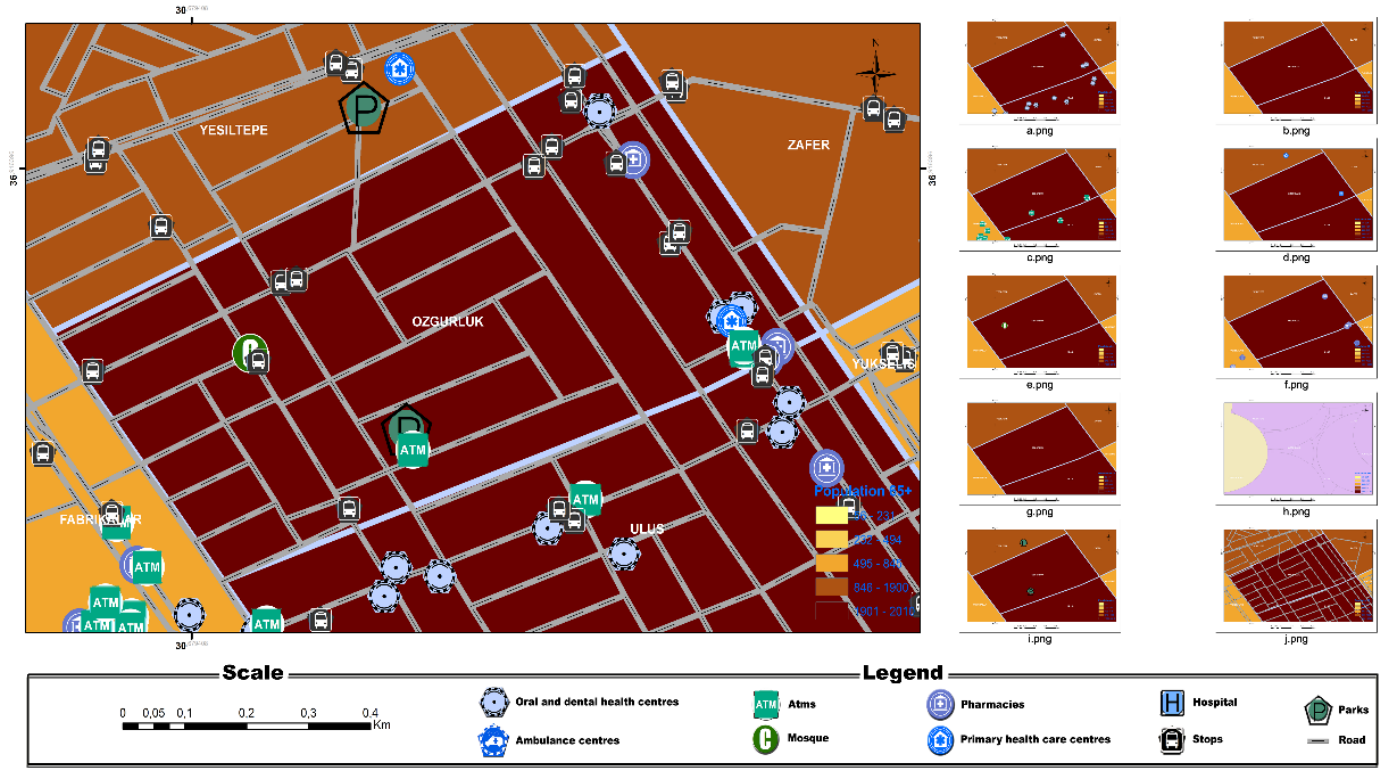

Figure 6. Location and density map of selected criteria in Özgürlük Neighbourhood. 


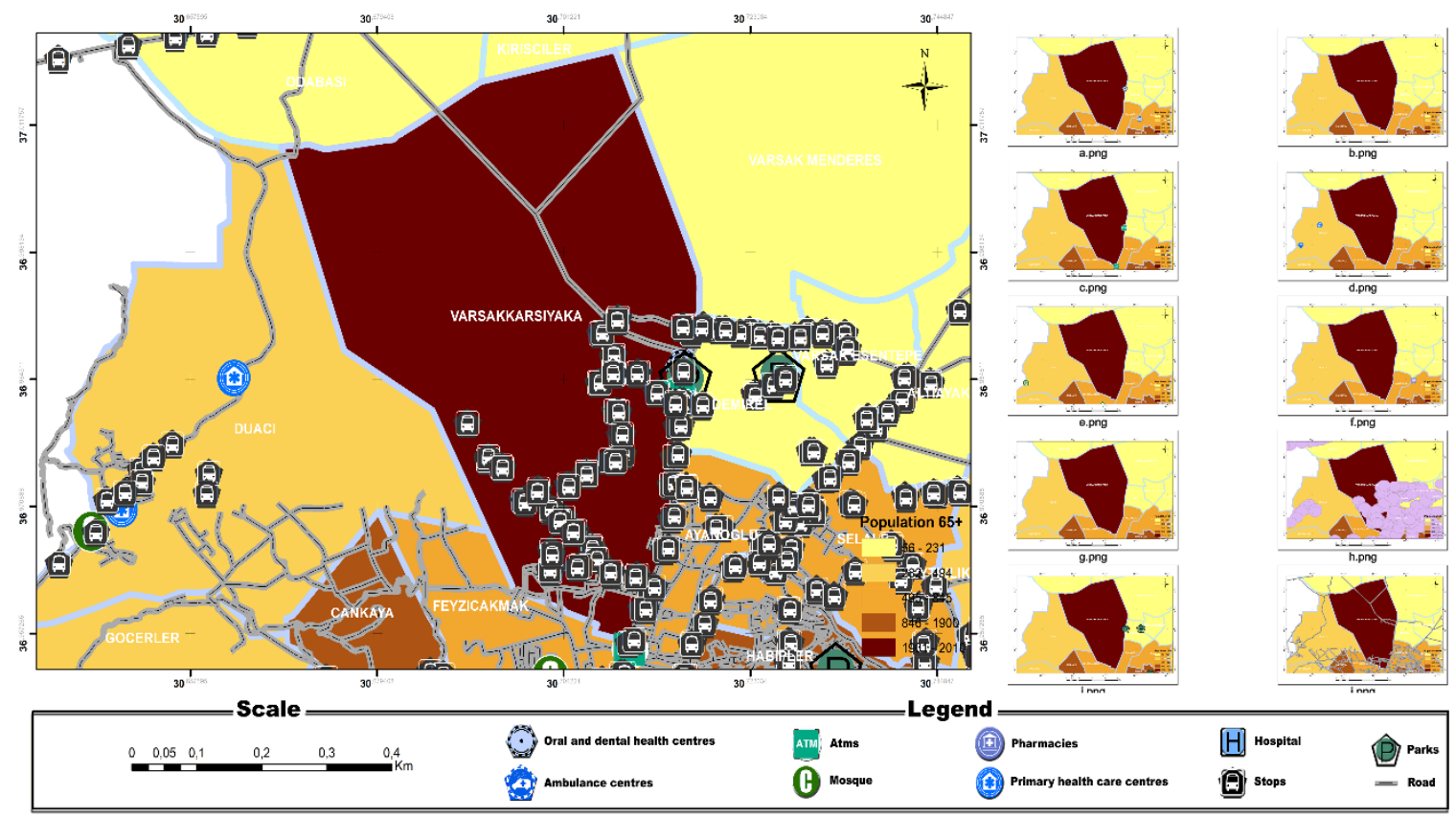

Figure 7. Location and density map of selected criteria in Varsak Neighbourhood.

neighbourhoods but none in Varsak neighbourhood even though it has the largest area. There is a pharmacy in Ulus and Özgürlük neighbourhood but none in Varsak neighbourhood.

- Public transport facilities are deemed important in the literature in terms of social participation of older people and access to other services (Cerin, Leslie, du Toit, Owen, \& Frank, 2007; Hirshorn \& Stewart, 2003; Schwanen \& Páez, 2010; Szell, 2018). In order to determine the distributions of the bus stops regarding walkability, a buffer analysis was applied at a radius of $\mathbf{4 0 0}$ meters, which is accepted as the walkability distance for older individuals in the literature (Carlson, York, \& Primomo, 2011; Cerin et al., 2007, 2013; Nagel, Carlson, Bosworth, \& Micheael, 2008; Pikora et al., 2006). There is a limited number of bus and tram stops in Ulus and Özgürlük neighbourhoods, and it is determined that they are found to be spatially sufficient as the bus and tram stops buffer layer has covered $100 \%$ of the area in Ulus and Özgürlük neighbourhoods. Although the number of stops is the highest in Varsak neighbourhood, they have been found to be irregular according to the spatial distribution.

- The roads of Ulus and Özgürlük neighbourhoods were well distributed. The roads of Varsak neighbourhood were irregularly distributed.

- Research reveals that recreational areas are necessary for active ageing, and areas outside home provide social inclusion to older people (Turel, Yigit, \& Altug, 2007; Yung, Conejos, \& Chan, 2016). Parks have an important role in terms of physical activity and the prevention of social exclusion of older individuals in Turkey. All three neighbourhoods have parks.
- Mosques are places older individuals visit on daily basis for social interaction, as well as for religious purposes. A study carried out in Turkey revealed that mosques need to be considered in urban planning from the perspectives of social participation and active ageing (Öztürk \& Kızıldoğan, 2017). There is only one mosque in Özgürlük, none in Varsak or Ulus. However, a close neighbourhood analysis showed that the maximum distance of mosques from the border of the selected neighbourhood is $900 \mathrm{~m}$. Older individuals are paid their pensions through ATMs and as they commonly prefer to withdraw money in parts, they use ATMs regularly. Use of ATM has been found to be important for older individuals' daily (Ergun \& Akyıldı, 2017). There are sufficient ATMs in the three neighbourhoods.

- The area of two neighbourhoods (Özgürlük and Ulus) is small in size, has a high population density, and most of the facilities selected in this research are located in these neighbourhoods. Varsak is the neighbourhood with the largest geographical area, however, there are fewer facilities compared to other neighbourhoods. The population density of all three neighbourhoods is presented in the age density map.

No hospitals and ambulance centres have been found in any of the three neighbourhoods. Therefore, the analysis of a close neighbourhood has been made via the generated maps (see Figure 8). According to the analysis, the hospitals and ambulance centres are, at most, $7.2 \mathrm{~km}$ away from the (Varsak, Ulus and Özgürlük) neighbourhoods, which does not indicate any difficulties regarding access to health services. Our research findings show 

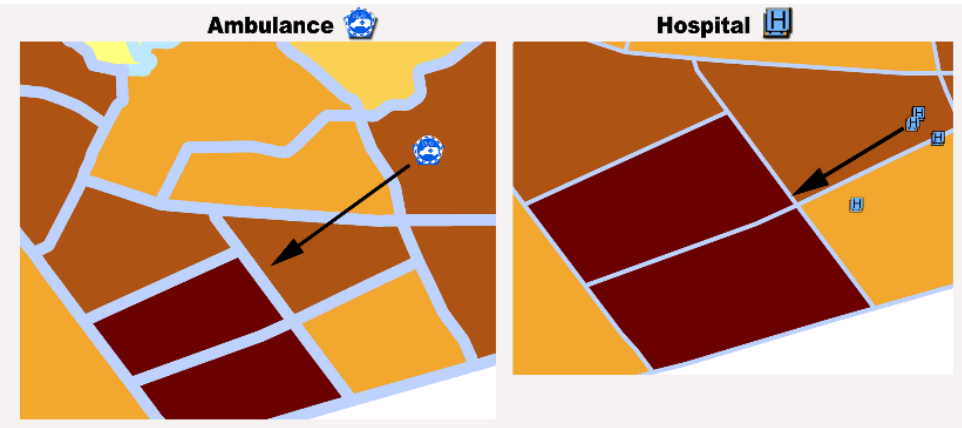

Figure 8. Map of the close neighbourhood.

that an analysis of a close neighbourhood should be performed by means of GIS to obtain more accurate data, as numerical-regional analyses might not be sufficient.

\subsection{AHP Analysis Findings}

Selected criteria (oral and dental health centres, ambulance centres, primary health care centres, pharmacies and transportation network, ATMs, parks, and stops in neighbourhoods) were evaluated in terms of accessibility and availability.

Weight points of each neighbourhood are shown in Table 4. Accordingly, the total weight score of Ulus neighbourhood is 2,24 which is the largest score, the total weight score of Özgürlük neighbourhood is 2,67 and the total weight score of Varsak neighbourhood is the highest which is found as 8,32 . A higher total weight score indicates a more liveable neighbourhood.

Table 4. Liveability score table.

\begin{tabular}{|c|c|c|c|c|c|c|c|c|c|}
\hline \multirow[b]{2}{*}{$\begin{array}{l}\text { Alphabetical } \\
\text { Order }\end{array}$} & \multirow[b]{2}{*}{ Symbol } & \multirow[b]{2}{*}{ Abbreviation } & \multirow[b]{2}{*}{ Coefficient } & \multirow[b]{2}{*}{$\begin{array}{l}\text { Ulus_- } \\
\text { Number }\end{array}$} & \multirow[b]{2}{*}{$\begin{array}{c}\text { Özgürlük_ } \\
\text { Number }\end{array}$} & \multirow[b]{2}{*}{$\begin{array}{l}\text { Varsak_ } \\
\text { Number }\end{array}$} & \multicolumn{3}{|c|}{ Score $=$ Coefficient $*$ Number } \\
\hline & & & & & & & $\begin{array}{l}\text { Ulus_- } \\
\text { Score }\end{array}$ & $\begin{array}{l}\text { Özgürlük_ } \\
\text { Score }\end{array}$ & $\begin{array}{c}\text { Varsak_ } \\
\text { Score }\end{array}$ \\
\hline 1_Oral_Dental & & a & 0,035591 & 9 & 3 & 1 & 0,32 & 0,11 & 0,04 \\
\hline 2_Ambulance & & $b$ & 0,277102 & - & - & - & 0 & 0 & 0 \\
\hline 3_ATM & & c & 0,027601 & 3 & 2 & 1 & 0,08 & 0,055 & 0,028 \\
\hline $\begin{array}{l}\text { 4_Primary } \\
\text { Health Care } \\
\text { Center }\end{array}$ & & $d$ & 0,212156 & 1 & 1 & - & 0,21 & 0,21 & 0 \\
\hline 5_Mosque & & e & 0,055247 & - & 1 & - & 0 & 0,056 & 0 \\
\hline 6_Pharmacy & & $f$ & 0,086717 & 2 & 2 & - & 0,17 & 0,17 & 0 \\
\hline 7_Bus_AntRAY & & $\mathrm{h}$ & 0,152013 & 9 & 13 & 79 & 1,37 & 1,98 & 12,01 \\
\hline 8_Hospital & & g & 0,103985 & - & - & - & 0 & 0 & 0 \\
\hline 9_Park & & $\mathrm{i}$ & 0,031832 & 1 & 1 & 1 & 0,032 & 0,032 & 0,032 \\
\hline 10_Roads & & j & 0,017756 & 3 & 3 & 1 & 0,053 & 0,053 & 0,018 \\
\hline Total & & & & & & & 2,24 & 2,67 & 8,32 \\
\hline
\end{tabular}


The criteria were re-evaluated taking the size of the neighbourhood into consideration. On the assumption that the size of the neighbourhood (see Table 5) can affect the numeric size of the selected criteria. The analysis table that includes the size of geographical areas of neighbourhoods can be seen in Table 6. Accordingly, a value (number) of each criterion has been calculated per square meter and multiplied by the weight score obtained from the AHP analysis. In this case, the "liveability score" of neighbourhoods are as follows: Ulus = $0,53 \times 10^{-6}$, Varsak $=4,7 \times 10^{-6}$, Özgürlük $=6,5 \times 10^{-6}$ (see Table 6).

The liveability ranking of the neighbourhoods has changed from Varsak, Özgürlük, Ulus to Özgürlük, Ulus, and Varsak, taking the size of the geographical area into consideration (see Table 7). Accordingly, adding some details about the space can lead to accurate results and may provide more detailed data.

\section{Discussion}

In this research, health, transportation, and social facilities that older people use are rated by expert group depending on the importance and frequency of use. The spatial facilities of three neighbourhoods in an urban area with the highest density of older individuals were evaluated in terms of the liveable areas for older individuals and the existing situation was graded by AHP

Table 5. 65+ population and area size of neighbourhoods.

\begin{tabular}{clcr}
\hline Item no. & The neighbourhood & Number of 65+ people & Area (square meters) \\
\hline 1 & Ulus & 2010 & $424239 \mathrm{~m}^{2}$ \\
2 & Özgürlük & 1999 & $399241 \mathrm{~m}^{2}$ \\
3 & Varsak & 1941 & $18396258 \mathrm{~m}^{2}$ \\
\hline
\end{tabular}

Table 6. Liveability score table according to area size.

\begin{tabular}{|c|c|c|c|c|c|c|c|c|c|}
\hline \multirow[b]{2}{*}{$\begin{array}{l}\text { Alphabetical } \\
\text { Order }\end{array}$} & \multirow[b]{2}{*}{ Symbol } & \multirow[b]{2}{*}{$\begin{array}{l}\text { Abbre- } \\
\text { viation }\end{array}$} & \multirow[b]{2}{*}{ Coefficient } & \multirow[b]{2}{*}{$\begin{array}{l}\text { Ulus_- } \\
\text { Number }\end{array}$} & \multirow[b]{2}{*}{$\begin{array}{l}\text { Özgürlük__ } \\
\text { Number }\end{array}$} & \multirow[b]{2}{*}{$\begin{array}{l}\text { Varsak_ } \\
\text { Number }\end{array}$} & \multicolumn{3}{|c|}{ Score $=$ Coefficient $*$ Number } \\
\hline & & & & & & & $\begin{array}{l}\text { Ulus_ } \\
\text { Score }\end{array}$ & $\begin{array}{l}\text { Özgürlük_ } \\
\text { Score }\end{array}$ & $\begin{array}{c}\text { Varsak_ } \\
\text { Score }\end{array}$ \\
\hline 1_Oral_Dental & & $\mathrm{a}$ & 0.035591 & $9 / 424239$ & 3/399241 & $1 / 18396258$ & $0,8 * 10^{-6}$ & $0,3 * 10^{-6}$ & $0,1 * 10^{-6}$ \\
\hline 2_Ambulance & & $b$ & 0.277102 & - & - & - & 0 & 0 & 0 \\
\hline 3_ATM & & c & 0.027601 & $3 / 424239$ & 2/399241 & $1 / 18396258$ & $0,2 * 10^{-6}$ & $0,1 * 10^{-6}$ & $0,1 * 10^{-6}$ \\
\hline $\begin{array}{l}\text { 4_Primary } \\
\text { Health Care } \\
\text { Center }\end{array}$ & & $d$ & 0.212156 & $1 / 424239$ & $1 / 399241$ & - & $0,5 * 10^{-6}$ & $0,5 * 10^{-6}$ & 0 \\
\hline 5_Mosque & & $\mathrm{e}$ & 0.055247 & - & $1 / 399241$ & - & 0 & $0,1 * 10^{-6}$ & 0 \\
\hline 6_Pharmacy & & $f$ & 0.086717 & $2 / 424239$ & 2/399241 & - & $0,8 * 10^{-6}$ & $0,4 * 10^{-6}$ & 0 \\
\hline 7_Bus_AntRAY & & $\mathrm{h}$ & 0.152013 & $9 / 424239$ & 13/399241 & $79 / 18396258$ & $3,2 * 10^{-6}$ & $4,9 * 10^{-6}$ & $4,3 * 10^{-6}$ \\
\hline 8_Hospital & & g & 0.103985 & - & - & - & 0 & 0 & 0 \\
\hline 9_Park & & $\mathrm{i}$ & 0.031832 & $1 / 424239$ & 1/399241 & $1 / 18396258$ & $0,1 * 10^{-6}$ & $0,1 * 10^{-6}$ & $0,1 * 10^{-6}$ \\
\hline 10_Roads & & j & 0.017756 & $3 / 424239$ & $3 / 399241$ & $1 / 18396258$ & $0,1 * 10^{-6}$ & $0,1 * 10^{-6}$ & $0,1 * 10^{-6}$ \\
\hline Total & & & & & & & $0,53 * 10^{-6}$ & $6,5 * 10^{-6}$ & $4,7 * 10^{-6}$ \\
\hline
\end{tabular}


Table 7. Results of AHP analysis based on 65+ ratio and area size.

\begin{tabular}{|c|c|c|c|c|c|}
\hline Item no. & The Neighbourhood & $\begin{array}{l}\text { Number of } \\
65+\text { people }\end{array}$ & Area(squaremeters ${ }^{2}$ ) & $\begin{array}{c}\text { Method } 1 \\
\text { (number-weight } \\
\text { rating) }\end{array}$ & $\begin{array}{c}\text { Method } 2 \\
\text { (square meters-number- } \\
\text { weight rating) }\end{array}$ \\
\hline 1 & Ulus & 2010 & 424,239 & 2.24 & $0,53 * 10^{-6}$ \\
\hline 2 & Özgürlük & 1999 & 399,241 & 2.66 & $6,5^{*} 10^{-6}$ \\
\hline 3 & Varsak & 1941 & $18,396,258$ & 8.32 & $4,7 * 10^{-6}$ \\
\hline
\end{tabular}

analysing tools. According to the findings, the most important deficiency for health care services in the selected neighbourhoods is that there are no ambulance centres or hospitals in the neighbourhoods, which could reveal a health access issue. Close neighbourhood analysis was performed for all neighbourhoods, with maps generated by GIS and it was found that there are hospital and ambulance facilities in the regions nearby, though this is not considered as a risk factor as ambulance services exist in a close neighbourhood, maximum $7.2 \mathrm{~km}$ away. In this type of research, it is not sufficient to evaluate the quantitative data, space utilization and close neighbourhood analyses of the research area should also be carried out. Bus and tram stops were found to be adequate in all three regions, supported by buffer analysis. In the research, Varsak neighbourhood was found to have the lowest score in terms of health care services and transportation facilities compared to other neighbourhoods. Considering the area utilisation characteristics of the Varsak region, most of the neighbourhood had agricultural characteristics.

The global trend of population ageing requires the consideration of urban planning suitable for older individuals. The older population is not homogenous, therefore, a universal "age-friendly" or "liveable city" model is not easy to implement. The planning decisions of implementations for older individuals is multidimensional and has to take the diversity of older individuals into consideration (Buffel et al., 2012; Glicksman, Clark, Kleban, Ring, \& Hoffman, 2014; Hwang, Glass, Gutzmann, \& Shin, 2008; Shank \& Cutchin, 2016).

Criteria of age-friendly cities are not considering individual priorities and sociocultural differences. We have aimed to reveal the local needs of older individuals by adding them to expert groups and letting them decide the criteria. We have used multiple decision-making analyses to select and to weight the facilities for local older people. Health-related facilities were scored as a high priority whereas facilities deemed important for western cultures such as community centres and libraries were not found to be important. Also, mosques were considered as important by older individuals. Public transportation was mentioned prior to private transportation. It can be concluded that spatial priorities differed in our research according to socio-economic and cultural features.

The findings from this research can contribute to the literature on the implementation of age-friendly, liveable city concept using AHP analysis process and evaluating this process from the local perspective. However, applications may change according to different socio-cultural and economic features of local communities. The priorities of spatial facilities for older individuals living in local communities should be considered in urban planning.

Some facilities commonly used for age-friendly cities (housing, vehicles, community centres, libraries, etc.) were not considered in this research, as the criteria were selected by the expert group. Another limitation is that only the existence and the numbers of spatial facilities/criteria were evaluated. A qualitative and detailed analysis could contribute to the evaluation of liveable neighbourhoods.

\section{Conclusion}

The International City/County Management Association (ICMA, 2003) has revealed the strategies required for active ageing and age-friendly liveable communities for older individuals in their report Active Living for Older Adults: Management Strategies for Healthy and Livable Communities. The concept of liveable communities includes basic components such as transportation facilities, health care services and consumption, recreation and social facilities. The liveable community concept does not only affect the health and lifestyles of older adults but also contributes to the urban planning decisions of local governments. Therefore, the first step towards the planning of liveable cities is to determine the distribution of existing services and facilities for older people in cities (ICMA, 2003). In Livable Communities: An Evaluation Guide, Kihl, Brennan, Gabhawala, List and Mittal (2005) describe the physical conditions in urban areas such as transportation networks, public transport facilities, consumption facilities, health care centres, recreation facilities, and areas for social networking as important components for an independent life in old age without social exclusion. This article has evaluated health care services, transportation facilities, social and recreational facilities of the cities and neighbourhoods in terms of liveable environments for older people from a local perspective. This study attempts to evaluate the liveability of neighbourhoods by using multi-criteria. A general formulation is proposed where the varied criteria and scoring according to the selected region and needs provides researchers with flexibility. 


\section{Conflict of Interests}

The authors declare no conflict of interests.

\section{References}

Atlanta Regional Commission. (2009). Lifelong communities: A regional guide to growth and longevity. Atlanta, GA: Atlanta Regional Commission.

Beard, J. R., \& Montawi, B. (2015). Age and the environment: The global movement towards agefriendly cities and communities. Journal of Social Work Practice, 29(1), 5-11. http://dx.doi.org/10. 1080/02650533.2014.993944

Beard, J. R., \& Petitot, C. (2010). Ageing and urbanization: Can cities be designed to foster active ageing? Public Health Reviews, 32(2), 427-450.

Biggs, S., \& Carr, A., (2015). Age and child-friendly cities and the promise of intergenerational space. Journal of Social Work Practice, 29(1), 99-112. http://dx.doi. org/10.1080/02650533.2014.993942

Bookman, A. (2008). Innovative models of ageing in place: Transforming our communities for an aging population. Community, Work \& Family, 11(4), 419-438.

Buffel, T., Phillipson, C., \& Scharf, T. (2012). Ageing in urban environments: Developing 'age-friendly' cities. Critical Social Policy, 32(4), 597-617.

Carlson, T., York, S., \& Primomo, J. (2011). The utilization of geographic information systems to create a site selection strategy to disseminate an older adult fall prevention program. The Social Science Journal, 48(1), 159-174.

Cerin, E., Leslie, E., du Toit, L., Owen, N., \& Frank, L. D. (2007). Destinations that matter: Associations with walking for transport. Health \& Place, 13(3), 713-724.

Cerin, E., Lee, K. Y., Barnett, A., Sit, C. H., Cheung, M. C., Chan, W. M., \& Johnston, J. M. (2013). Walking for transportation in Hong Kong Chinese urban elders: A cross-sectional study on what destinations matter and when. International Journal of Behavioral Nutrition and Physical Activity, 10(1), 78.

Ergun, A. D., \& Akyıldız, D. (2017). Yaşılıarın Gündelik Yaşam Pratikleri Ve Sosyal Algılar: Menemen Örneği [Everyday life practices and social perceptions of the elderly: Example of Menemen]. Mehmet Akif Ersoy Üniversitesi Sosyal Bilimler Enstitüsü Dergisi, 9(22), 500-509.

Fidler, D., Olson, R., \& Bezold, C. (2011). Evaluating a long-term livable communities strategy in the U.S. Futures, 43, 690-696. https://doi.org/10.1016/ j.futures.2011.05.010

Findlay, R. A. (2003). Interventions to reduce social isolation amongst older people: Where is the evidence? Ageing \& Society, 23(5), 647-658.

Gardner, I., Brooke, E., Ozanne, E., \& Kendig, H. (1999). Improving social networks, a research report: Improv- ing health and social isolation in the Australian veteran community. Melbourne: Lincoln Gerontology Centre, La Trobe University.

Glicksman, A., Clark, K., Kleban, M. H., Ring, L., \& Hoffman, C. (2014). Building an integrated research/ policy planning age-friendly agenda. Journal of Aging \& Social Policy, 26(1/2), 131-146.

Hirshorn, B. A., \& Stewart, J. E. (2003). Geographic information systems in community-based gerontological research and practice. Journal of Applied Gerontology, 22(1), 134-151.

Hwang, E., Glass, A. P., Gutzmann, J., \& Shin, K. J. (2008). The meaning of a livable community for older adults in the United States and Korea. Journal of Housing for the Elderly, 22(3), 216-239.

Hwang, E., \& Ziebarth, A. (2015). Walkability features for seniors in two livable communities: A case study. Housing and Society, 42(3), 207-221.

International City/County Management Association. (2003). Active living for older adults: Management strategies for healthy and livable communities. Washington, DC: ICMA.

Jensen, P. A., \& Maslesa, E. (2015). Value based building renovation: A tool for decision-making and evaluation. Building and Environment, 92, 1-9.

Kalache, A. (2016). Active ageing and age-friendly cities: A personal account. In T. Moulaert \& S. Garon (Eds.), Age-friendly cities and communities in international comparison (pp. 65-77). New York, NY: Springer.

Kihl, M., Brennan, D., Gabhawala, N., List, J., \& Mittal, P. (2005). Livable communities: An evaluation guide. Washington, DC: AARP Public Policy Institute.

Luo, W., \& Wang, F. (2003). Measures of spatial accessibility to health care in a GIS environment: Synthesis and a case study in the Chicago region. Environment and Planning B: Planning and Design, 30(6), 865-884.

Mollenkopf, H., Marcellini, F., Ruoppila, I., Széman, Z., Tacken, M., \& Wahl, H. W. (2004). Social and behavioural science perspectives on out-of-home mobility in later life: Findings from the European project MOBILATE. European Journal of Ageing, 1(1), 45-53.

Moulaert, T., \& Garon, S. (Eds.). (2015). Age-friendly cities and communities in international comparison: Political lessons, scientific avenues, and democratic issues. New York, NY: Springer.

Nagel, C. L., Carlson, N. E., Bosworth, M., \& Micheael, Y. (2008). The relation between the neighborhood built environment and walking activity among older adults. American Journal of Epidemiology, 168(4), 461-468.

Nicholls, S. (2001). Measuring the accessibility and equity of public parks: A case study using GIS. Managing Leisure, 6(4), 201-219.

Ogg, J. (2005). Social exclusion and insecurity among older Europeans: The influence of welfare regimes. Ageing \& Society, 25(1), 69-90.

Öztürk, A. Ç., \& Kızıldoğan, E. T. (2017). Yaşli Bireylerin Kentsel/Kamusal Mekanlari Kullanim Analizi: Eskişe- 
hir Örneği [The analysis of the use of elderly individuals of urban/public spaces: The case of Eskisehir]. Yaşlı Sorunları Araştırma Dergisi, 10(1), 1-13.

Paul, A., \& Sen, J. (2018). Livability assessment within a metropolis based on the impact of integrated urban geographic factors (IUGFs) on clustering urban centers of Kolkata. Cities, 74, 142-150.

Pikora, T. J., Giles-Corti, B., Knuiman, M. W., Bull, F. C., Jamrozik, K., \& Donovan, R. J. (2006). Neighborhood environmental factors correlated with walking near home: Using SPACES. Medicine and Science in Sports and Exercise, 38(4), 708-714.

Ruth, M., \& Franklin, R. S. (2014). Livability for all? Conceptual limits and practical implications. Applied Geography, 49, 18-23.

Saaty, T. L. (1980). The analytic hierarchy process. New York, NY: McGraw-Hill.

Schwanen, T., \& Páez, A. (2010). The mobility of older people: An introduction. Journal of Transport Geography, 18, 591-595.

Shank, K. S. H., \& Cutchin, M. P. (2016). Processes of developing 'community livability' in older age. Journal of Aging Studies, 39, 66-72.

Steels, S. (2015). Key characteristics of age-friendly cities and communities: A review. Cities, 47, 45-52.

Szell, M. (2018). Crowdsourced quantification and visualization of urban mobility space inequality. Urban Planning, 3(1), 1-21.

Turel, H. S., Yigit, E. M., \& Altug, I. (2007). Evaluation of elderly people's requirements in public open spaces: A case study in Bornova District (Izmir, Turkey). Building and Environment, 42(5), 2035-2045.

UN. (2015). World population ageing, 1950-2050. New York, NY: United Nations Publications.

UN. (2018). The 2018 revision of world urbanization prospects. New York, NY: Population Division of the UN Department of Economic and Social Affairs.

UN-Habitat. (2010). State of the world's cities 2010-2011:
Bridging the urban divide. London: Earthscan.

Wahl, H. W., Iwarsson, S., \& Oswald, F. (2012). Aging well and the environment: Toward an integrative model and research agenda for the future. The Gerontologist, 52(3), 306-316.

Warner, M. E., Xu, Y., \& Morken, L. J. (2017). What explains differences in availability of community healthrelated services for seniors in the United States? Journal of Aging and Health, 29(7), 1160-1181. https:// doi.org/10.1177/0898264316654675

Wey, W. M., \& Huang, J. Y. (2018). Urban sustainable transportation planning strategies for livable city's quality of life. Habitat International, 82, 9-27.

World Health Organization. (2002). Active ageing: A policy framework (Paper no WHO/NMH/NPH/02.8). Geneva: WHO Press.

World Health Organization. (2007). Global age-friendly cities: A guide. Geneva: WHO Press.

Yazdani, A. A., \& Tavakkoli-Moghaddam, R. (2012). Integration of the fish bone diagram, brainstorming, and AHP method for problem solving and decision making: A case study. The International Journal of Advanced Manufacturing Technology, 63(5/8), 651-657.

Yu, J., Liu, Y., Chang, G. L., Ma, W., \& Yang, X. (2011). Locating urban transit hubs: Multicriteria model and case study in China. Journal of Transportation Engineering, 137(12), 944-952.

Yung, E. H., Conejos, S., \& Chan, E. H. (2016). Public open spaces planning for the elderly: The case of dense urban renewal districts in Hong Kong. Land Use Policy, 59, 1-11.

Zarghami, E., Sharghi, A., Olfat, M., \& Kousalari, F. S. (2018). Using multi-criteria decision-making method (MCDM) to study quality of life variables in the design of senior residences in Iran. Ageing International, 43(3), 279-296.

\section{About the Authors}

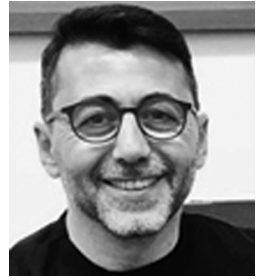

Ercüment Aksoy has been a Lecturer at Akdeniz University, Turkey, at the Department of Architecture, City Planning Programme, and the Geographic Information Systems in Vocational School of Technical Sciences, since 1995. His research area is geographic information systems and remote sensing applications. He is researching GIS and gerontology and the application of GIS in urban planning and has a particular interest in multi-criteria decision process applications.

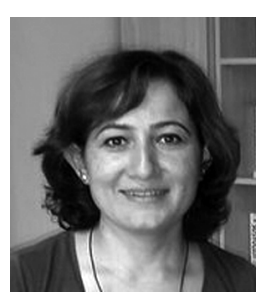

Nilufer Korkmaz-Yaylagul is an Associate Professor of the Gerontology Department at Akdeniz University, Turkey. She has trained as a landscape architect at the University of Ankara, Turkey, and has completed her MSc studies in the field of landscape architecture at the same university. She earned a PhD degree in Social Anthropology-Urban Anthropology from Hacettepe University in 2008. She has carried out post-doctoral research on health and older Turkish immigrants at the Institute of Population Ageing of the University of Oxford, UK. She has been involved in the teaching of ecology and anthropology of ageing and medical anthropology at Akdeniz University since 2009. She has a particular interest in environmental and social gerontology. 